сийского университета дружбы народов. Серия: Социология. 2020. Т. 20 . № 4. С. 801-820. https://10.22363/2313-2272-2020-20-4-801-820.

См., к примеру: Trantidis A. Clientelism and Economic Policy: Greece and the crisis. London; New York, 2016; Lyrintzis Ch. Greek Politics in the Era of Economic Crisis: Reassessing Causes and Effects / GreeSE Paper N 45. March 2011. URL: Ise.ac.uk/ Hellenic-Observatory/Publications/GreeSE-Papers (дата обращения: 12.04.2021).

3 Generations of Pork: How Greece's Political Elite Ruined the Country // Spiegel ONLINE. July 05, 2011. URL: https://www.spiegel.de/international/europe/generationsof-pork-how-greece-s-political-elite-ruined-the-country-a-772176.html (дата обращения: 11.04.2021).

4 Петрунина O.E. Греческая нация и государство в XVIII-XX вв. Очерки политического развития. М., 2010. С. 576.

Trantidis A. Clientelism and Economic Policy: Greece and the Crisis.

6 Tsoukas L. The Future of Greece in the European Union // Greece in the Twentieth Century / eds.: Th.A. Couloumbis, Th.C. Kariotis, F. Bellou. London; New York, 2004. P. 320.

7 Квашнин Ю.Д. Внутриполитическое развитие Греции в условиях кризиса // Современная Греция в мировой экономике и политике. М., 2013. С. 144.

8 Lefkofridi Z. National Political Parties and EU Policy Developments: The Case of Greece Prior to the Crisis // Journal of Modern Greek Studies. 2014. Vol. 32. N 2. P. 287-311. https://10.1353/mgs.2014.0037.

9 Mavrozacharakis E., Tzagarakis S. About Political Change in Greece / MPRA Paper N 72173. June 2016. P. 9. URL: https://mpra.ub.uni-muenchen.de/72173/ (дата обращения: 12.04.2021).

\title{
Колебания
}

этническото состава населения Истрии в конце XIX - начале XXI вв. и проблема их исторической и статистической интерпретации*

Александр Александрович Пивоваренко,

Институт славяноведения Российской академии наук Москва, Российская Федерация; e-mail: aleksandar.a.p@ya.ru Ключевые слова: Истрия, Хорватия, Италия, фрашизм, Югославия

* Исследование выполнено при поддержке гранта РНФ по проекту 20-78-10030 «Языковые и культурные контакты в условиях социальных трансформаций у национальных меньшинств альпийско-паннонского региона». 


\section{Fluctuations in the Ethnic Composition of the Population of Istria in the Late Nineteenth - Early Twenty-First Centuries and the Problem of Their Historical and Statistical Interpretation}

Alexander A. Pivovarenko,

Institute of Slavic Studies, Russian Academy of Sciences, Moscow, Russian Federation; e-mail: aleksandar.a.p@ya.ru Keywords: Istria, Croatia, Italy, fascism, Yugoslavia

Цель статьи - рассмотреть вопрос о содержании феномена региональной идентичности населения полуострова Истрия. Данные переписи населения 2011 г. в Хорватии фиксируют значительное многообразие идентификации населения региона в этнонациональном, религиозном и языковом планах. Характерно, что практически по каждому из параметров мы не видим полного численного совпадения: так, по данным переписи 2011 г., 156,2 тыс. населения составили католики, при том, что лишь 142 тыс. самоопределились как хорваты ${ }^{1}$.

Общая численность населения на полуострове Истрия составила 208 тыс. человек. Среди статистически значимых присутствующих на полуострове сообществ, помимо хорватов-католиков, необходимо выделить сербов (7 206 человек), православных (7 220 чел.), итальянцев (12,5 тыс. человек), бошняков (6 146 человек, при том что лишь 2866 человек указали своим родным так называемый «боснийский» язык), албанцев (2393 чел.). Значительную долю населения составляют агностики, атеисты либо уклоняющиеся от религиозного самоопределения (33 тыс. человек). Заслуживает внимание фригурирующая в переписи категория «Региональное самосознание», под которой принято понимать сторонников так называемой «особой истрийской идентичности». По сравнению с переписью 2001 г. (8 865 человек) число сторонников такой версии самоопределения увеличилось в три раза до 25203 человек ${ }^{2}$. 
Этнополитическая картина полуострова является достаточно пестрой, что указывает на необходимость ее тщательного изучения с привлечением статистических и нарративных данных, а также проведения опросов населения. Крайне важно оценить динамику изменения состава населения полуострова Истрия, на протяжении ХХ в. являвшегося предметом территориальных споров между Италией и Югославией, Словенией и Хорватией.

В работе охарактеризованы изменения этнополитического состава населения Истрии в период с конца XIX по начало XXI в. и проанализирована дискуссия, существующая по этому вопросу в хорватской и итальянской историографии. Ключевой проблемой в рассматриваемом сюжете является асимметричность имеющейся информации и интерпретаций в смысле их точности. Если ситуация до середины XX в. характеризовалась отсутствием верифицированных данных (в этот период Истрия находилась в составе Италии) при наличии достаточно четких интерпретаций (в частности, хорватская историография утверждает, что политика итальянского фрашизма была направлена на подавление хорватского населения и его ассимиляцию) ${ }^{3}$, то начиная со второй половины 1940-х гг. подтвержденные данные югославских переписей уравновешиваются дискуссией об итальянских беженцах из Истрии. В частности, итальянская историография обвиняет Югославию в подавлении итальянского нацменьшинства ${ }^{4}$, в то время как югославско-хорватская историография стремится к занижению масштабов оттока итальянского населения из Истрии ${ }^{5}$.

Таким образом, существует серьезная дискуссия между югославско-хорватской и итальянской историографией о составе населения Истрии, причинах и масштабах происходивших этнополитических изменений, связанных с ассимиляцией либо вытеснением тех или иных групп населения. Хотя вопрос политической принадлежности полуострова сегодня не является открытым - Истрия признается частью государственного пространства Хорватии - дискуссия несет в себе и определенный политический элемент. В частности, 
в начале 1990-х гг. наиболее фундаменталистские представители хорватской историографии, сторонники централизованной Хорватии, видели в истрийском региональном движении признаки итальянского сепаратизма 6.

Анализ имеющегося комплекса данных позволяет болееменее определенно констатировать следующие тенденции.

Прежде всего, можно говорить о наличии в Истрии френомена подвижной («плавающей») идентичности как реакции на политические события XX в., закончившиеся образованием независимой Хорватии. В некотором смысле он может быть тождественен ситуации в Черногории, где в начале 1990-х гг. понятие «черногорец» было связано с сербским самоопределением, а в период независимости стало синонимом отдельной политической нации. Впрочем, более точный ответ на этот вопрос требует отдельного исследования.

Во-вторых, необходимо внимательнее отследить причины «перетекания» самоопределения из группы «Остальные» в группу «Региональное самосознание», которое имело место в 2001-2011 гг. Не менее важен вопрос, насколько региональное самосознание в Истрии формируется под влиянием Италии как государства с более мощным экономическим потенциалом и культурной надстройкой.

Существует вопрос несовпадения языковой и политической идентичности. В ходе переписи 1991 г. лишь 57,7\% населения Истрии самоопределились как хорваты. При этом $76,6 \%$ назвали хорватский язык в качестве родного ${ }^{7}$ Увеличение сторонников хорватского самоопределения с 1991 по 2001 г. (со 135 до 148 тыс., или до 71,9 \%) говорит о «подгонке» этнических данных к языковым. Однако механизм перехода пока что непонятен.

Наконец, следует обратить внимание на терминологическую дискуссию вокруг понятий «истриянин» (хорв. Istrijan) и «истранин». Как отмечает хорватский исследователь Н. Шетич, понятие «истриянин», являясь естественным с точки зрения географии, в историческом смысле имеет негативную коннотацию, поскольку в ХХ в. оно использовалось сначала «итальянско-фрашистской», а затем «югославско-ком- 
мунистической» политикой («одним “истриянином” больше означало, что одним хорватом стало меньше»). Сегодня же истриянин в понимании сторонников хорватского централизма - это «принадлежащий к суверенной хорватской нации гражданин Хорватии, независимо от того, ощущает ли он себя на национальном уровне итальянцем или хорватом». Наряду с этим существует стремление утвердить альтернативное определение «истранин» (хорв. Istranin), под которым понимается житель хорватской Истрии (Истрийской жупании), разделяющий нормы хорватского литературного языка вне зависимости от национального самоощущения ${ }^{8}$.

Этнический, историко-политический и статистический аспект, как и дискуссия о терминах, являются элементами ключевого вопроса: что же формирует наднациональную «особую» истрийскую общность и можно ли говорить о ее сохранении либо укреплении в существующих историко-политических условиях? Ответ на него требует дополнительного исследования с привлечением широкого комплекса документальных, статистических и нарративных данных.

\section{примечания}

1 Popis stanovništva, kućanstava i stanova 2011. Stanovništvo prema državljanstvu, narodnosti, vijeri i materinskom jeziku // Državni zavod za statistiku Republike Hrvatske. URL: https://www.dzs.hr/Hrv_Eng/publication/2012/SI-1469.pdf (дата обращения: 08.01.2021). S. 52-63.

2 Ibid. S. 52-53.

3 Dukovski D. Egzodus talijanskog stanovništva iz Istre 1945-1956 // Časopis za suvremenu povijest. 2001. Vol. 33. N 3. S. 635.

4 Giuricin E. Talijanska nacionalna zajednica (1945-2003) // Istra kroz vrijeme. Pregled povijesti Istre sa osvrtom na grad Rijeku / ured. E. Ivetic. Rovinj; Rijeka; Trieste, 2009. S. 653.

5 Dukovski D. Egzodus talijanskog stanovništva iz Istre 1945-1956. S. 635.

6 Šetić N. O nacionalnom identitetu Istre u XX. stoljeću // Identitet Istre - ishodište i perspective / ured. M. Manin et al. Zagreb, 2006.

7 Klemenčić M., Kušar V., Richter Ž. Promjene Narodnosnog sastava Istre. Prostorna analiza popisnih podataka 1880-1991 // Društvena istraživanja: časopis za opća društvena pitanja. 1993. Vol. 2. N 4-5 (6-7). S. 615.

8 Šetić N. O nacionalnom identitetu Istre u XX. stoljeću. S. 129, 133. 